\title{
Sun-Earth System Interaction studies over Vietnam: an international cooperative project
}

\author{
C. Amory-Mazaudier ${ }^{1}$, M. Le Huy ${ }^{2}$, Y. Cohen ${ }^{3}$, V. Doumbia ${ }^{4, *}$, A. Bourdillon ${ }^{5}$, R. Fleury ${ }^{6}$, B. Fontaine ${ }^{7}$, C. Ha
} Duyen $^{2}$, A. Kobea ${ }^{4}$, P. Laroche ${ }^{8}$, P. Lassudrie-Duchesne ${ }^{6}$, H. Le Viet ${ }^{2}$, T. Le Truong ${ }^{2}$, H. Luu Viet ${ }^{2}$, M. Menvielle ${ }^{1}$, T. Nguyen Chien ${ }^{2}$, A. Nguyen Xuan ${ }^{2}$, F. Ouattara ${ }^{9}$, M. Petitdidier ${ }^{1}$, H. Pham Thi Thu ${ }^{2}$, T. Pham Xuan ${ }^{2}$, N. Philippon ${ }^{* *}$, L. Tran Thi ${ }^{2}$, H. Vu Thien ${ }^{10}$, and P. Vila ${ }^{1}$

${ }^{1}$ CETP/CNRS, 4 Avenue de Neptune, 94107 Saint-Maur-des-Fossés, France

${ }^{2}$ Institute of Geophysics, Vietnamese Academy of Science and Technology , 18 Hoang Quoc Viet, Cau Giay, Hanoï, Vietnam

${ }^{3}$ IPGP, 4 Avenue de Neptune, 94107 Saint-Maur-des-Fossés, France

${ }^{4}$ Laboratoire de Physique de l'Atmosphère, Université d'Abidjan Cocody 22 B.P. 582, Abidjan 22, Côte d'Ivoire

${ }^{5}$ Institut d'Electronique et de Télécommunications, Université de Rennes Bât 11D, Campus Beaulieu, 35042 Rennes, cédex,

France

${ }^{6}$ ENST, Université de Bretagne Occidentale, CS 83818, 29288 Brest, cédex 3, France

${ }^{7}$ CRC , Faculté des Sciences, 6 Boulevard Gabriel, F 21004 Dijon cédex 04, France

${ }^{8}$ Unité de Recherche Environnement Atmosphérique, ONERA, 92332 Chatillon, cédex, France

${ }^{9}$ University of Koudougou, Burkina Faso

${ }^{10}$ Laboratoire signaux et systèmes, CNAM, 292 Rue saint Martin, 75141 Paris cédex 03, France

${ }^{*}$ V. Doumbia previously signed V. Doumouya

**affiliation unknown

Received: 15 June 2006 - Revised: 19 October 2006 - Accepted: 8 November 2006 - Published: 21 December 2006

\begin{abstract}
During many past decades, scientists from various countries have studied separately the atmospheric motions in the lower atmosphere, in the Earth's magnetic field, in the magnetospheric currents, etc. All of these separate studies lead today to the global study of the Sun and Earth connections, and as a consequence, new scientific programs (IHY- International Heliophysical Year, CAWSES- Climate and Weather in the Sun-Earth System) are defined, in order to assume this new challenge. In the past, many scientists did not have the possibility to collect data at the same time in the various latitude and longitude sectors. Now, with the progress of geophysical sciences in many developing countries, it is possible to have access to worldwide data sets. This paper presents the particularities of geophysical parameters measured by the Vietnamese instrument networks. It introduces a cooperative Vietnamese-IGRGEA (International Geophysical Research Group Europe Africa) project, and presents, for the first time, to the international community, the geophysical context of Vietnam.

Concerning the ionosphere: since 1963, during four solar cycles, the ionosonde at Phu Thuy (North Vietnam) was operating. The Phu Thuy data exhibits the common features for the ionospheric parameters, previously observed in other longitude and latitude sectors. The critical frequencies of
\end{abstract}

Correspondence to: C. Amory-Mazaudier

christine.mazaudier@cetp.ipsl.fr the E, F1 and F2 ionospheric layers follow the variation of the sunspot cycle. F2 and E critical frequencies also exhibit an annual variation. The first maps of TEC made with data from GPS receivers recently installed in Vietnam illustrate the regional equatorial pattern, i.e. two maxima of electronic density at $15^{\circ} \mathrm{N}$ and $15^{\circ} \mathrm{S}$ from the magnetic equator and a trough of density at the magnetic equator. These features illustrate the equatorial fountain effect.

Concerning the Earth's magnetic field: a strong amplitude of the equatorial electrojet was first observed by the CHAMP satellite at the height of $400 \mathrm{~km}$ in the Vietnamese longitude sector. In this paper we compare the ground magnetic observations of the Indian and Vietnamese magnetometer networks. This comparison highlights the regional structure of the amplitude of the equatorial electrojet, which is stronger in Vietnam than in India.

Concerning the monsoon: Vietnam exhibits a strong monsoon and has mainly one rainy season peaking in August, hence associated with the southwest monsoon flow. But some monsoon variability from one place to another is related to the orography. In the mountainous northern regions of Vietnam, there is an "early" monsoon peaking in July. In the coastal regions between $12^{\circ} \mathrm{N}$ and $19^{\circ} \mathrm{N}$ the monsoon season is centered on October.

Concerning lightning: Vietnam is a country of strong atmospheric storms with some areas of very intense lightning

Published by Copernicus GmbH on behalf of the European Geosciences Union. 
in North Vietnam $\left(22,5^{\circ} \mathrm{N}, 105^{\circ} \mathrm{E}\right)$ and in South Vietnam $\left(11^{\circ} \mathrm{N}, 107^{\circ} \mathrm{E}\right)$. In North Vietnam strong lightning is associated with the most intense rainy region.

Keywords. Ionosphere (Electric fields and currents) - Meteorology and dynamics (Tropical meteorology) - Geomagnetism and paleomagnetism (Time variations, diurnal to secular)

\section{Introduction}

For 15 years the IGRGEA (International Geophysical Research Group in Europe Africa) is involved in geophysics in Africa (Mazaudier et al., 1993; Amory-Mazaudier et al., 2005). This group started in 1995 in order to continue the scientific work done from 1991 to 1995 in the frame of the IEEY (International Year of the Equatorial Electrojet). The IEEY project had been decided at the VANCOUVER Assembly of the IAGA, in 1987, on the request of the Interdivisional Commission on Developing Countries (ICDC). During the IEEY, Doumouya and Cohen (2004) discovered that the amplitude of the daily variation of the Earth's magnetic field observed with the CHAMP satellite is stronger in the Asian sector than in the African one. These observations led to the cooperation between the IGRGEA and the Hanoï Institute of Geophysics (Vietnam), HIG, in order to understand this phenomena.

It is well known that the equatorial electrojet circulating in the ionospheric dynamo layer results from the atmospheric motions. These atmospheric motions are mainly due to migrating atmospheric tides generated at lower altitudes (Chapman and Lindzen, 1970). By collision, the atmosphere drags ions though the Earth's magnetic field (Stewart, 1882) and generates the equatorial electrojet itself at the origin of the daily variation of the Earth's magnetic field. More recently, Hagan and Forbes (2002), showed that nonmigrating waves, due to deep convection events (related to tropical meteorological storms, as well as monsoon) in the boundary layer and in the troposphere, can affect the atmospheric motions in the dynamo layer. Therefore, it is necessary to study the equatorial electrojet in the frame of the Sun-Earth connections, including worldwide data sets from the low atmosphere to the Sun.

Taking into account all of these facts, IGRGEA and HIG decided to participate together in international programs such as CAWSES (Climate and Weather in the Sun-Earth System) and IHY(International Heliophysical Year), both devoted to the Sun-Earth connections.

Vietnamese scientists published in a Vietnamese journal various scientific results on the magnetic and ionosonde data (Truong Quang and Le Huy, 1987; Le Huy, 1999; Le Huy and Pham Van, 2001). But at the present time these scientific results are not available for the international community.

This introductive paper presents to the international community the Vietnamese scientific instrument networks and data sets, and the morphological features of the geophysical parameters. Some of these morphological features are different from the other longitude sectors. The first section is devoted to the scientific frame. The second section presents the existing Vietnamese network of atmospheric stations, magnetometers, ionosondes, GPS receivers and magnetotelluric stations. In this section we recall all the data sets recorded in Vietnam during the last decades. The third section highlights some interesting observations characterizing Vietnam and then we conclude.

\subsection{Scientific frame}

We concentrate our studies on physical processes (dynamics, electrodynamics, magnetic) operating in the Earth's environment at various time scales (several minutes to several solar cycles) and space scales (planetary, regional and local). This is the reason why we are analysing atmospheric, as well as ionospheric parameters in the same paper.

Figure 1 (originally from Amory-Mazaudier, 1983) is a schematic view of some connections between the Sun and the Earth. The vertical dimension represents the distance from the Sun to the Earth and the horizontal dimension the distance from the pole (right side) to the equator (left side). In green our main interests are underlined: 1) the monsoon in the tropical and equatorial troposphere and in the atmospheric boundary layer (bottom left), 2) the equatorial electrojet (middle left) flowing in the ionosphere along the magnetic equator and its connections with the auroral electrojets (middle right), 3) the Earth's magnetic field variation due to the electric currents flowing in the ionosphere and in the magnetosphere (bottom), 4) the solar activity (top).

\subsection{Solar radiations}

The Sun's radiations reach the environment of the Earth at all latitudes. These radiations are the source of various physical processes of the Sun-Earth System.

In the stratosphere, sources of migrating atmospheric tides propagate toward higher altitudes. They generate in the dynamo E layer (altitudes comprised between 90 and $190 \mathrm{~km}$ ) the circulation of ionospheric electric currents by the dynamo effect (Stewart 1882). This dynamo layer exists mainly on the dayside of the Earth's, as a consequence of the photoionization by solar radiations. These daily regular ionospheric currents are the source of the daily regular variations of the Earth's magnetic field $S_{R}$ (Mayaud, 1965a, 1965b), green vertical arrows indicate the connection between the ionospheric electric currents and the Earth's magnetic field. The dynamo layer process is schematised on the left side of the figure, where it concerns all the latitudes.

At the bottom left side of Fig. 1 for equatorial and tropical latitudes, the physical process of deep convection in the boundary layer and troposphere, due to the monsoon, influences the upper levels of the atmosphere. During the 


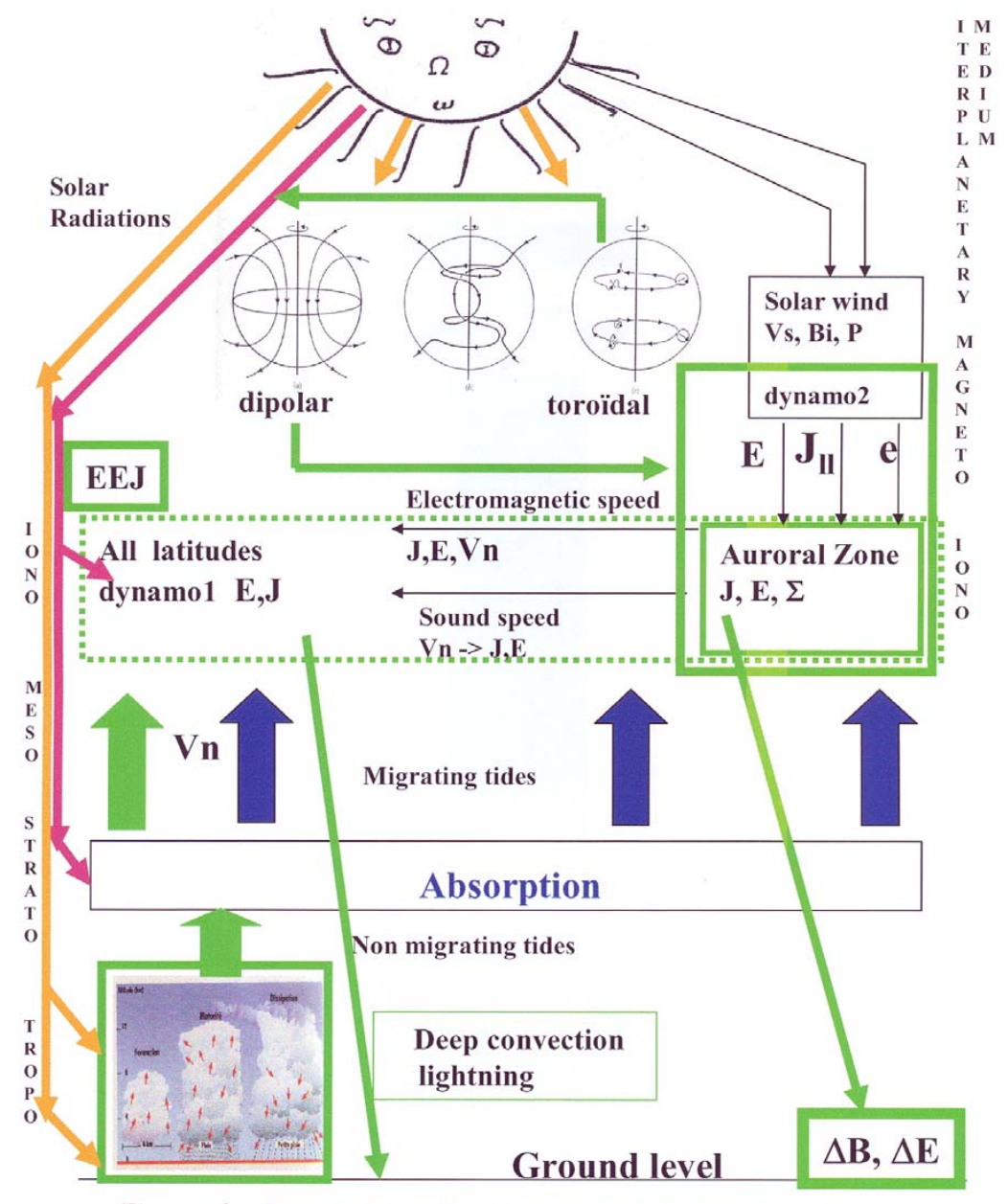

Figure : Sun Earth relationships, Dynamic and Electromagnetism ( Amory-Mazaudier et al., 2005 )

Fig. 1. Schematic figure concerning some processes involved in the Sun-Earth system.

monsoon, large electrical field variations occur in clouds with large lightning activity (Richard et al., 1986; Petitdidier et Laroche, 2005). Recent theoretical and experimental studies in the tropical and equatorial zones revealed the importance of the tropospheric latent heat release in the excitation of migrating and nonmigrating tides in the middle and upper atmosphere (Hagan and Forbes, 2002; Fukao et al., 2003; Gurubaran et al., 2005). These tides can affect the ionospheric electric currents and as a consequence, the variation of the Earth's magnetic field.

\subsection{Solar wind}

The solar wind interacts with the magnetosphere through two major physical processes: the viscous interaction (Axford and Hines, 1961) and the reconnection (Dungey, 1961). These physical processes affect the whole magnetosphere and also the auroral ionosphere. In the Fig. 1, middle part, the auroral ionosphere (right side) is connected to the mid- dle and equatorial ionosphere (left side). Two main physical processes are involved in the electrodynamic coupling between the high and low latitudes: 1) the prompt penetration of the magnetospheric convection electric field (Nishida et al., 1966; Nishida 1968; Vasyliunas, 1970; Kobéa et al., 2000) and 2) the ionospheric disturbance dynamo process (Blanc and Richmond, 1980; Mazaudier and Venkateswaran, 1990; Le Huy and Amory-Mazaudier, 2005).

\subsection{Solar magnetic cycles}

To develop a pertinent analysis of geophysical data it is necessary to know exactly the geomagnetic context of all the observations. In our project, for the analysis of the long series of Vietnamese data, we will follow the classification of magnetic activity established by Legrand and Simon (1989), whjo along with Simon and Legrand (1989) analysed and classified the geomagnetic activity in terms of the solar activity (due to the two magnetic solar cycles), by using the 
Table 1a. Geographic coordinates of the Vietnamese network containing instruments for upper atmospheric studies.

\begin{tabular}{|l|l|c|c|}
\hline \multirow{2}{*}{ Code } & \multirow{2}{|c|}{ Name } & \multicolumn{2}{|c|}{ Geographic, deg } \\
\cline { 3 - 4 } & & Lat. & Long. \\
\hline SPA & Sapa & 22.333 & 103.833 \\
\hline PHU & Phu Thuy & 21.033 & 105.950 \\
\hline DAL & Da Lat & 11.95 & 108.483 \\
\hline BCL & Bac Lieu & 9.283 & 105.733 \\
\hline HCM & Ho Chi Minh city & 10.883 & 106.547 \\
\hline HAN & Ha Noi & 21.030 & 105.900 \\
\hline HUE & Hue & 16.400 & 107.400 \\
\hline NBA & Noi Bai & 21.200 & 105.925 \\
\hline THN & Thai Nguyen & 21.583 & 105.833 \\
\hline MCH & Moc Chau & 20.085 & 104.633 \\
\hline BTH & Binh Thuan & 10.821 & 107.721 \\
\hline
\end{tabular}

Table 1b. Geographic coordinates of the Vietnamese meteorological stations.

\begin{tabular}{|c|c|c|c|}
\hline \multirow[t]{2}{*}{ No. } & \multirow[t]{2}{*}{ Name } & \multicolumn{2}{|c|}{ Geographic, deg } \\
\hline & & Lat. & Long. \\
\hline 1 & Dien Bien & 21.40 & 103.02 \\
\hline 2 & Hoa Binh & 20.82 & 105.33 \\
\hline 3 & Lai Chau & 22.07 & 103.15 \\
\hline 4 & Mai Chau & 20.67 & 105.05 \\
\hline 5 & Moc Chau & 20.82 & 104.70 \\
\hline 6 & Muong $\mathrm{Te}$ & 22.38 & 102.83 \\
\hline 7 & Son La & 21.32 & 103.88 \\
\hline 8 & Yen Chau & 21.05 & 104.28 \\
\hline 9 & Bac Quang & 22.50 & 104.87 \\
\hline 10 & Yen Bai & 21.72 & 104.85 \\
\hline 11 & Van Chan & 21.58 & 104.52 \\
\hline 12 & Cao Bang & 22.65 & 106.25 \\
\hline 13 & Ha Giang & 22.82 & 104.98 \\
\hline 14 & Bai Chay & 20.97 & 107.07 \\
\hline 15 & Lang Son & 21.87 & 106.77 \\
\hline 16 & Thai Nguyen & 21.58 & 105.83 \\
\hline 17 & Vinh Yen & 21.28 & 105.58 \\
\hline 18 & Bac Giang & 21.28 & 106.22 \\
\hline 19 & Lang & 21.03 & 105.85 \\
\hline 20 & Nam Dinh & 20.40 & 106.15 \\
\hline 21 & Ninh Binh & 20.23 & 105.97 \\
\hline 22 & Phu Lien & 20.80 & 106.63 \\
\hline 23 & Son Tay & 21.13 & 105.50 \\
\hline 24 & Bai Thuong & 19.92 & 105.37 \\
\hline 25 & Dong Hoi & 17.47 & 106.62 \\
\hline 26 & $\mathrm{Ha}$ Tinh & 18.40 & 105.90 \\
\hline 27 & Hue & 16.40 & 107.70 \\
\hline 28 & Nam Dong & 16.15 & 107.72 \\
\hline 29 & Tuong Duong & 19.28 & 104.43 \\
\hline 30 & Thanh Hoa & 19.82 & 105.78 \\
\hline 31 & Tinh Gia & 19.58 & 105.78 \\
\hline 32 & Vinh & 18.67 & 105.67 \\
\hline 33 & $\mathrm{Ba} \mathrm{To}$ & 14.77 & 108.72 \\
\hline 34 & Da Nang & 16.03 & 108.18 \\
\hline 35 & Nha trang & 12.25 & 109.20 \\
\hline 36 & Phan Thiet & 10.93 & 108.10 \\
\hline 37 & Quang Ngai & 15.13 & 108.78 \\
\hline 38 & Quy Nhon & 13.77 & 109.22 \\
\hline 39 & Tuy Hoa & 13.08 & 109.28 \\
\hline 40 & Ayunpa & 13.42 & 108.43 \\
\hline 41 & Bao Loc & 11.47 & 107.80 \\
\hline 42 & Ban $\mathrm{Me}$ thuot & 12.67 & 108.05 \\
\hline 43 & Da Lat & 11.95 & 108.43 \\
\hline 44 & PLaycu & 13.98 & 108.00 \\
\hline 45 & Ca Mau & 9.17 & 105.17 \\
\hline 46 & Can Tho & 10.03 & 105.78 \\
\hline 47 & Phu Quoc & 10.22 & 103.97 \\
\hline 48 & Rach Gia & 10.00 & 105.08 \\
\hline 49 & Tan Son Nhat & 10.82 & 106.67 \\
\hline 50 & Vung tau & 10.33 & 107.08 \\
\hline
\end{tabular}


Table 1c. Geographic coordinates of the GPS stations.

\begin{tabular}{|l|l|c|c|}
\hline \multirow{2}{*}{ GPS observatories } & \multicolumn{2}{c|}{ Geopgraphic Coordinates } \\
\cline { 3 - 4 } & & Latitude & Longitude \\
\hline 1 & Kunm (China) & $25.02000^{\circ} \mathrm{N}$ & $102.79700^{\circ} \mathrm{E}$ \\
\hline 2 & Hanoi (Vietnam) & $21.04740^{\circ} \mathrm{N}$ & $105.79970^{\circ} \mathrm{E}$ \\
\hline 3 & Hue (Vietnam) & $16.45920^{\circ} \mathrm{N}$ & $107.59270^{\circ} \mathrm{E}$ \\
\hline 4 & Hoc Mon (Vietnam) & $10.84860^{\circ} \mathrm{N}$ & $106.55980^{\circ} \mathrm{E}$ \\
\hline 5 & Ntus (Singapour) & $1.34580^{\circ} \mathrm{N}$ & $103^{\circ} 67995^{\circ} \mathrm{E}$ \\
\hline 6 & Bako (Indonesia) & $6.49106^{\circ} \mathrm{S}$ & $106.84891^{\circ} \mathrm{E}$ \\
\hline
\end{tabular}

centennial series of the aa index (Mayaud, 1972, 1973, 1975; Delouis and Mayaud, 1975) and ssc (Mayaud, 1975). They defined four classes: magnetic quiet activity, fluctuating activity, stream activity and shock activity.

They showed that the dipolar solar cycle, which controls the solar wind, is at the origin of $91.5 \%$ of the geomagnetic activity (magnetic quiet activity, fluctuating activity and stream activity). The sunspot solar cycle, which controls the EUV and UV radiations, generates only $8.5 \%$ of the geomagnetic activity (shock activity).

At the top of Fig. 1 we plotted the geometry of the field lines of the two solar cycles from Friedman (1986), the left panel corresponds to the dipolar solar field, the right panel to the torroïdal solar field and the middle panel to the transition phase between the dipolar and torroïdal solar fields.

\section{Vietnamese network and data sets}

Vietnam extends in geographic latitudes nearly from $8^{\circ} \mathrm{N}$ (magnetic equator) to $23.365^{\circ} \mathrm{N}$ and in longitude from $102^{\circ} \mathrm{E}$ to $110^{\circ} \mathrm{E}$. For many years the Institute of Geophysics has maintained several networks of instruments. Figure 2 gives the location of the different stations involved in external geophysical measurements and Table 1a provides the geographic coordinates of these stations. In Fig. 2, the atmospheric stations are quoted by red circles, the magnetometers by blue circles, the ionosonde located at Phu Thuy by a green square and the two meteorological radars at Hanoï and Ho Chi Minh City by black squares.

Since 2005, new instruments were brought to Vietnam:

- three GPS receivers are quoted by violet pentagons in Fig. 1 (two given by the University of Rennes and one by the University of Brest),

- a mobile magnetotelluric station was given by IPGP.

In addition, one ionosonde (green square ) will be set up by the National Institute of Information and Communication technology (NICT) from Japan; at the end of the year at Baclieu a station located below the equatorial electrojet in the frame of the cooperation project between NICT and IGP.

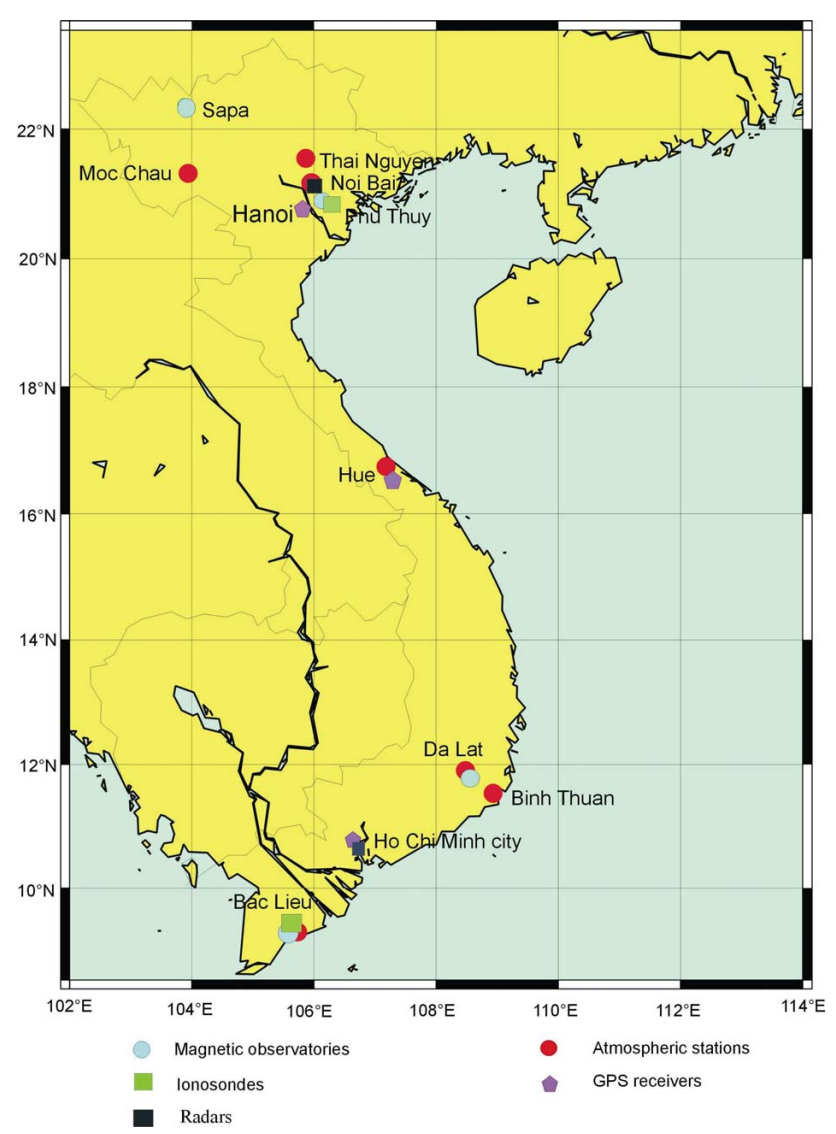

Fig. 2. Map of the Vietnamese network: Ionosondes (green square), GPS receivers (violet pentagone), Magnetometers (blue circles) and Atmospheric stations (red circles).

The Institute of Geophysics also maintains a network of 26 seismic stations which is not concerned by the present project. Table 2 gives the recorded physical parameters in each station and the data sets. In Table 2, the period of digital records for each instrument is also noticed. We must mention here that another institute of Vietnam, the meteorological service, maintains 172 meteorological stations, 14 stations with solar radiations measurements, and 63 stations 
Table 2. Physical parameters, data sets available, and period of digital records for each station.

\begin{tabular}{|c|c|c|c|}
\hline $\begin{array}{l}\text { Type and } \\
\text { measurements }\end{array}$ & Name & Beginning year & Digital data \\
\hline \multirow{4}{*}{$\begin{array}{l}\text { Magnetic } \\
\text { H, D, Z comp. } \\
\text { F total intensity }\end{array}$} & Sapa & 1957 & \\
\hline & Phu Thuy & 1968 & 1993 - now \\
\hline & Da Lat & 1981 & 2004 - now \\
\hline & Bac Lieu & 1988 & 1998 - now \\
\hline \multirow{2}{*}{$\begin{array}{l}\text { Ionospheric } \\
\text { vertical }\end{array}$} & Phu Thuy & 1962 & 1995 -now \\
\hline & Bac Lieu & Dec. 2005 & all \\
\hline \multirow{2}{*}{ radars } & Hanoï & 2001 & all \\
\hline & Ho Chi Minh & 2001 & all \\
\hline \multirow{3}{*}{$\begin{array}{l}\text { GPS } \\
\text { Scintillation, TEC }\end{array}$} & Ha Noi & March 2005 & all \\
\hline & Hue & December 2005 & all \\
\hline & Ho Chi Minh city & May 2005 & all \\
\hline \multirow{5}{*}{$\begin{array}{l}\text { Atmospheric } \\
\text { Lightnings, } \\
\text { Temperature, ... }\end{array}$} & Moc Chau & 2003 & all \\
\hline & Thai Nguyen & 2003 & all \\
\hline & Phu Thuy & 2003 & all \\
\hline & Noi Bai & 2003 & all \\
\hline & Binh Thuan & 2003 & all \\
\hline
\end{tabular}

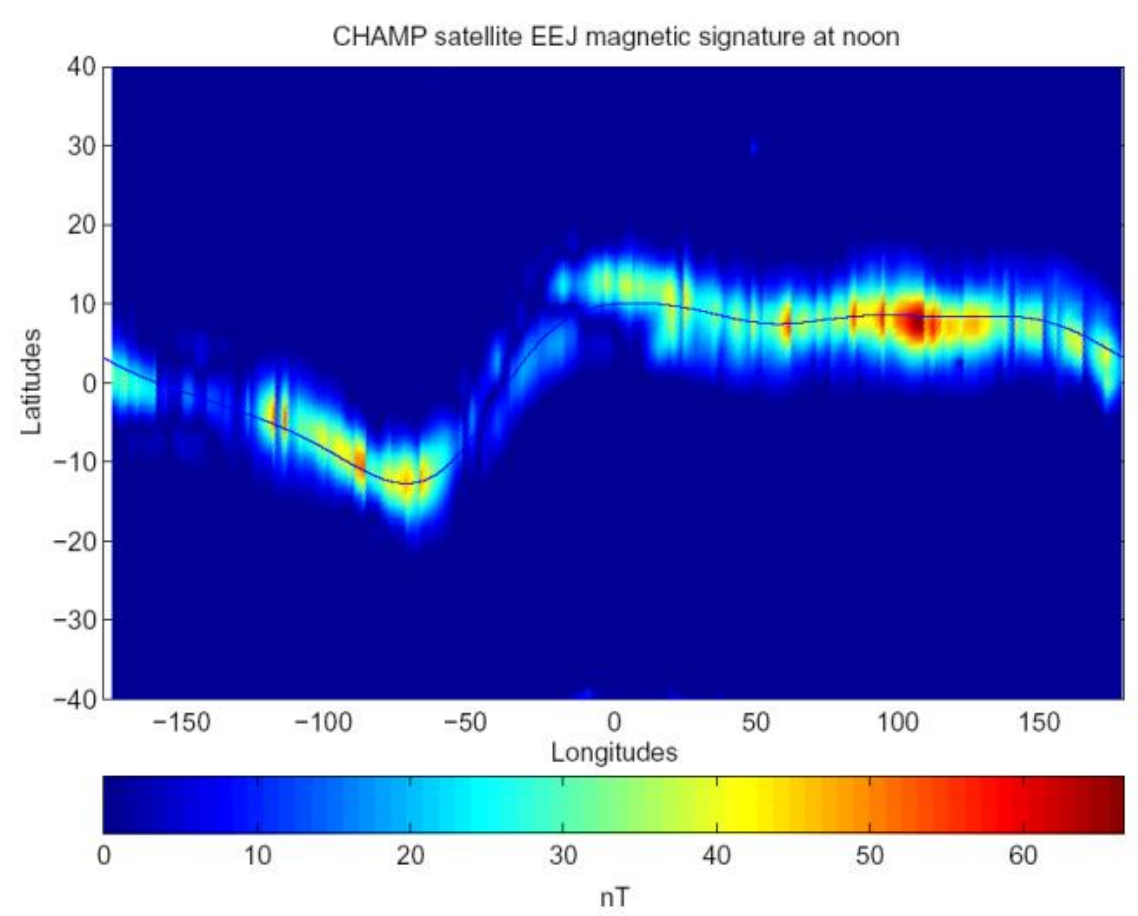

Fig. 3. Noon EEJ magnetic signature in August and September 2001 derived by CHAMP satellite measurements. This plot represents the absolute values of the EEJ magnetic effects along the dip-equator (figure from Doumouya and Cohen, 2004).

with barometric pressure measurements. The oldest data are from 1940 and will be used for the scientific study of the atmospheric boundary layer. The meteorological stations are listed in Table $1 \mathrm{~b}$.

\section{Main morphological features of geophysical parame- ters in Vietnam}

\subsection{Earth's magnetic field}

During the International equatorial electrojet Year project, the IGRGEA group analysed the Equatorial Electrojet in the African sector and compared the African observations to the other longitude sectors. Doumouya and Cohen (2004) ob- 

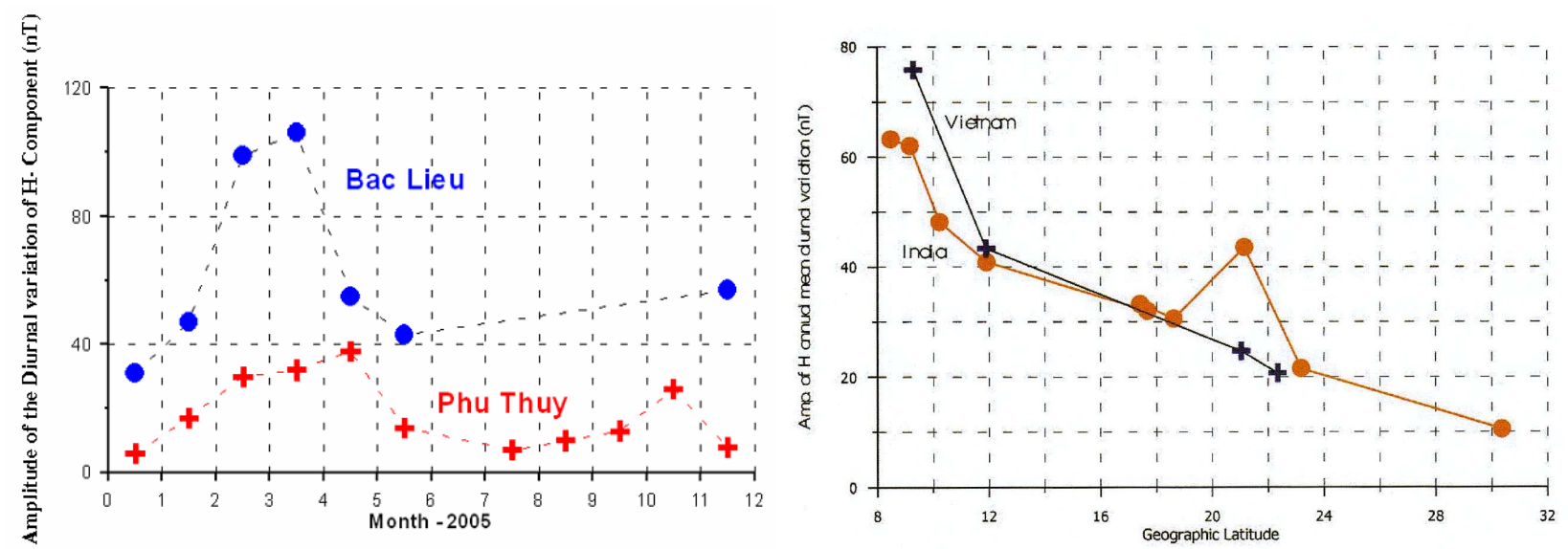

Fig. 4. Variations of the mean annual amplitude of the H component of the Earth's magnetic field observed at Bac Lieu and Phu Thuy (top panel) and latitudinal profiles of the mean annual value of the H component for the year 1996, the red profiles with circles are for the Indian network and blue profiles with crosses for the Vietnamese network (bottom panel).

Table 3. Geographic coordinates of the Indian magnetometer chain.

\begin{tabular}{|l|c|c|}
\hline \multirow{2}{*}{ Observatories } & \multicolumn{2}{|c|}{ Geographic coordinates } \\
\cline { 2 - 3 } & Longitude & Latitude \\
\hline Sabhawala & $77^{\circ} 48^{\prime} \mathrm{E}$ & $30^{\circ} 22^{\prime} \mathrm{N}$ \\
\hline Ujjain & $75^{\circ} 47^{\prime} \mathrm{E}$ & $23^{\circ} 11^{\prime} \mathrm{N}$ \\
\hline Nagpur & $79^{\circ} 05^{\prime} \mathrm{E}$ & $21^{\circ} 09^{\prime} \mathrm{N}$ \\
\hline Alibag & $72^{\circ} 52^{\prime} \mathrm{E}$ & $18^{\circ} 37^{\prime} \mathrm{N}$ \\
\hline Visakhapatnam & $8^{\circ} 19^{\prime} \mathrm{E}$ & $17^{\circ} 41^{\prime} \mathrm{N}$ \\
\hline Hyderabad & $78^{\circ} 33^{\prime} \mathrm{E}$ & $17^{\circ} 25^{\prime} \mathrm{N}$ \\
\hline Pondicherry & $79^{\circ} 55^{\prime} \mathrm{E}$ & $11^{\circ} 55^{\prime} \mathrm{N}$ \\
\hline Kodaikanal & $77^{\circ} 28^{\prime} \mathrm{E}$ & $10^{\circ} 14^{\prime} \mathrm{N}$ \\
\hline Ettaiyapuram & $78^{\circ} 01^{\prime} \mathrm{E}$ & $09^{\circ} 10^{\prime} \mathrm{N}$ \\
\hline Trivandrum & $76^{\circ} 58^{\prime} \mathrm{E}$ & $08^{\circ} 29^{\prime} \mathrm{N}$ \\
\hline
\end{tabular}

served a strong amplitude of magnetic signature of the equatorial electrojet over Vietnam. This result led to the comparative studies between the African and Asian sectors. Figure 3 from Doumouya and Cohen (2004) shows the intensity of the equatorial electrojet magnetic signature at noon. These observations are derived from the Champ satellite data. In this figure we clearly identify a strong intensity in the longitude sector $100^{\circ}$ and $110^{\circ} \mathrm{E}$. Vietnam is located nearly between geographic longitudes $102^{\circ}$ to $110^{\circ} \mathrm{E}$ and geographic latitudes $8.5^{\circ}$ to $23.4^{\circ} \mathrm{N}$. The magnetic equator is at the geographic latitude of $8^{\circ} \mathrm{N}$.

In the top panel of Fig. 4 the monthly mean diurnal amplitudes are plotted of the horizontal $\mathrm{H}$ component of the Earth's magnetic field measured at Bac Lieu (blue curve) and Phu Thuy (red curve). Bac Lieu is located below the magnetic equator and Phu Thuy at a geographic latitude of $21^{\circ} \mathrm{N}$. The strong amplitude observed at Bac Lieu is the sig- nature of the equatorial electrojet. At Bac Lieu we observe a maximum of the amplitude of the $\mathrm{H}$ component in April. At Phu Thuy we observed two peaks in May and November. Due to missing data in Bac Lieu we cannot observe the second maximum expected. It is well known that geomagnetic activity exhibits a semi annual component but its maxima occur around equinoxes. In the present case, at Phu Thuy, the maxima occur in May and November. This delay of the maxima relative to geographic equinoxes needs more investigation, namely is it a specificity of the Vietnamese longitude sector?

In the bottom panel of Fig. 4 the annual mean diurnal amplitudes are plotted of the $\mathrm{H}$ component for the Vietnamese magnetic network in blue and for the Indian magnetometers network in red, for the 1996 minimum solar activity period. Table 3 gives the geographic coordinates of the Indian magnetometers network. At equatorial latitudes 


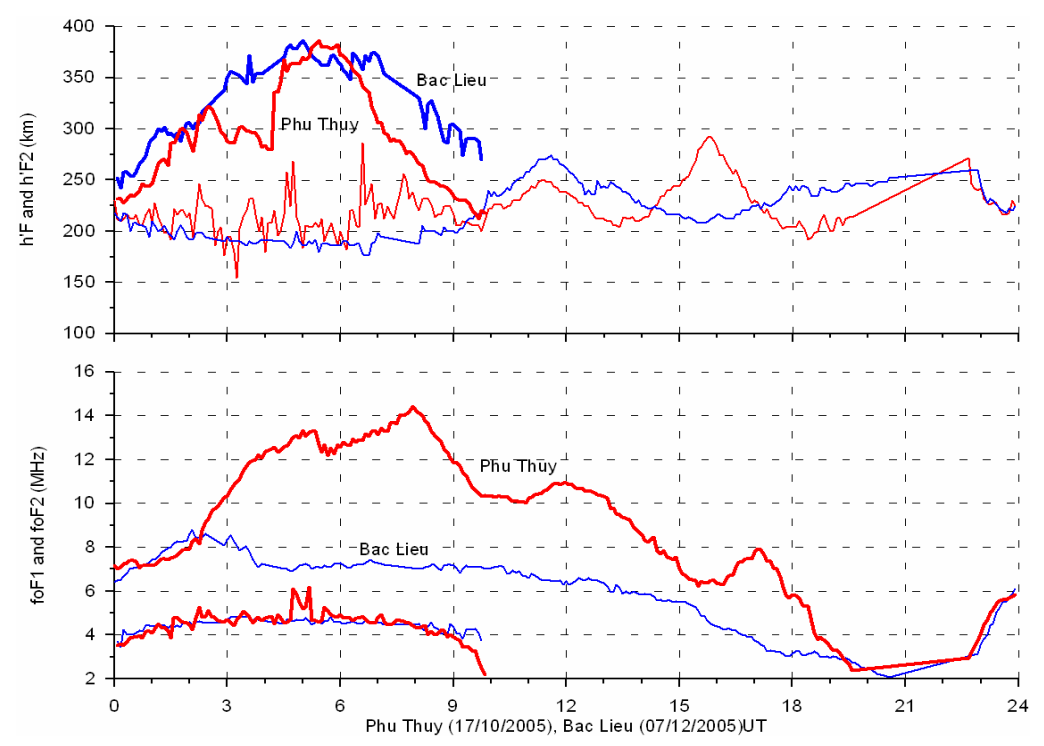

Fig. 5. Variations of the virtual heights and critical frequencies of the $F 1$ and $F 2$ layers for two different locations and two different days: data from Bac Lieu at the magnetic equator (blue curves) on 7 December 2005 and data from Phu Thuy at tropical latitudes (red curves) on 10 October 2005. The top panel corresponds to the virtual heights and the bottom panel to the critical frequencies.

the amplitude of $\mathrm{H}$ component observed in Vietnam at the ground level is greater than the amplitude of the H component observed in India. These observations are in good agreement with the preceding satellite observations (Fig. 3).

\subsection{Ionosphere}

Figure 5 illustrates the variations of ionospheric parameters at Bac Lieu (blue curves) on 7 December 2005 and at Phu Thuy (red curves) on 17 October 2005. The top panel show the virtual heights of the F1 and F2 layers and the bottom panel the critical frequency of the F1 and F2 layers. In the top panel the variation of the virtual heights exhibit the same pattern for the two different days in the two different locations. In the bottom panel the F1 critical frequency is the same at Bac Lieu and Phu Thuy, and the F2 critical frequency is greater at Phu Thuy. This panel illustrates the effect of the equatorial fountain: a trough of density at the magnetic equator and two maxima of density at tropical latitudes $15^{\circ} \mathrm{N}$ or south from the equatorial equator.

Figure 6, top panel, shows the amplitude of the total electron content (TEC), observed on 15 January 2006 in the northern hemisphere as a function of latitude (vertical axis) and UT time (horizontal axis), using the Vietnamese GPS data. We observe the dayside (yellow and orange colours) and the nightside (blue and grey colours). The north maximum crest occurs between $16^{\circ}$ and $22^{\circ} \mathrm{N}$ and around 06:00 UT (13:00 LT). Phu Thuy is at the latitude of $21^{\circ} \mathrm{N}$, just below this maximum. The bottom panel is similar to the top panel but concerns the two hemispheres on 22 January 2006 using the southeast GPS data (the three stations in
Vietnam and Kunm in China, Bako in Indonesia and Ntus in Singapore; Table 1c provides the geographic coordinates of some GPS stations). We clearly identify a very small TEC near the magnetic equator on the northern side and the two maxima in the two hemispheres. The magnetic equator is underlined by a dashed red line.

In Fig. 7 the ionospheric parameters are shown, derived from the ionograms of Phu Thuy during the four solar cycles 20, 21, 22, 23. From the top to the bottom of the figure the sunspot number, the critical frequencies of the F2, F1, E layers, the two frequencies for the Es layer (the critical frequency and the penetration frequency) and the virtual heights of the F2, F1, E and Es layers are successively plotted. The critical frequencies of the F2, F1 and E layers exhibit an annual variation superimposed on the sunspot cycle variation. These results are well known (Chapman and Bartels, 1940). The Es layer exhibits only an annual pattern.

\subsection{Meteorology and lightning}

Vietnam, and more largely the Indochina peninsula, is a monsoon region of transition between a typical tropical climate system (the south Asian monsoon) and a combined tropical-midlatitude system (the east Asian monsoon) (Chen and Chang, 1980; Zhang et al., 2002). The basic atmospheric features of the annual evolution over this country in link to precipitation is here succinctly presented using 2 basic atmospheric fields at regional scale: the wind speed at $925 \mathrm{hPa}$ (Fig. 8) for documenting the low level monsoon flow and the precipitable water, to take into account air moisture in the atmospheric column (Fig. 9). These data are provided 
from NCEP/DOE AMIP-II Reanalysis (R-2) over the period 1979-2004: R-2 improves upon the NCEP/NCAR Reanalysis $(\mathrm{R}-1)$ by fixing the errors and by updating the parameterizations of the physical processes.

Figures 8, 9 show that Vietnam registers two contrasted wind regimes: a northeast monsoon from October to April during the hemispheric winter and a southwest monsoon from April to September, peaking in northern summer. The former period is marked by low-level winds blowing southwestward while atmospheric moisture is rather low due to cold temperatures. Notice also that in January-March low level winds are diffluent by $15-17^{\circ} \mathrm{N}$ : they split into two main branches towards north and south, which generates divergence. As a result, precipitation tends to concentrate near the eastern coast. After April, however, the circulation in low levels changes drastically: a northeastward migration of the southwestern humid winds blowing from the Indian Ocean takes place (the southwest monsoon), associated with a general air moisture increase over the peninsula, peaking in JulySeptember and favouring rainfall over the whole country.

In order to better detail the impact on precipitation, a clustering algorithm (K-means) is applied on more than 40 selected series from the precipitation Vietnam network over the period 1960-2000, to separate 6 types of space/time variability (i.e. 6 classes of stations showing coherent rainfall variability in space and time (annual cycles, inter-monthly and interannual variability). K-means clustering is an algorithm to classify objects (here, in-situ stations) based on K number of groups, by minimizing the sum of squares of the distances between data and the corresponding cluster centroid. Here the clustering algorithm is repeated 1000 times with a new set of initial centroids to assess robustness. This allows us to separate the most robust signals from those occurring possibly by chance or if it is too noisy. Several K numbers ( 4 to 8 classes) have been tried and we report only on those with $\mathrm{K}=6$, which can be estimated as the most efficient choice with respect to the length of the series and network ( $\sim 40$ years and stations).

Figure 10 displays the location of the stations (Fig. 10a), along with mean annual evolutions (Fig. 10b) and interannual variability (Fig. 10c). Class 1 (blue) is clearly the most representative, with numerous stations north of $19^{\circ} \mathrm{N}$ and a few ones south of $13^{\circ} \mathrm{N}$ (Dalat, Buon Me thuat, Phan Thiet, Vung Tau et Can Tho). It shows that large regions of Vietnam register one rainy season starting in May and peaking in August $(\sim 250 \mathrm{~mm})$, in close association with the southwest monsoon flow (Fig. 8c). Over these areas mean annual rainfall ranges between $1500-1700 \mathrm{~mm}$ (mean $=1650 \mathrm{~mm}$ /year, standard deviation $=200 \mathrm{~mm}$ ) and do not show any long-term trend. Figure $3 \mathrm{c}$ shows, however, some multi-year fluctuations presenting a significant quasi-biennal signal at 2.4 years when a spectral analysis of the series is performed.

The other classes of variability (classes 2-6) can be viewed as regional alterations of the previous scheme. Classes 2-3 (pink and red) refer to the highlands north of the Red River
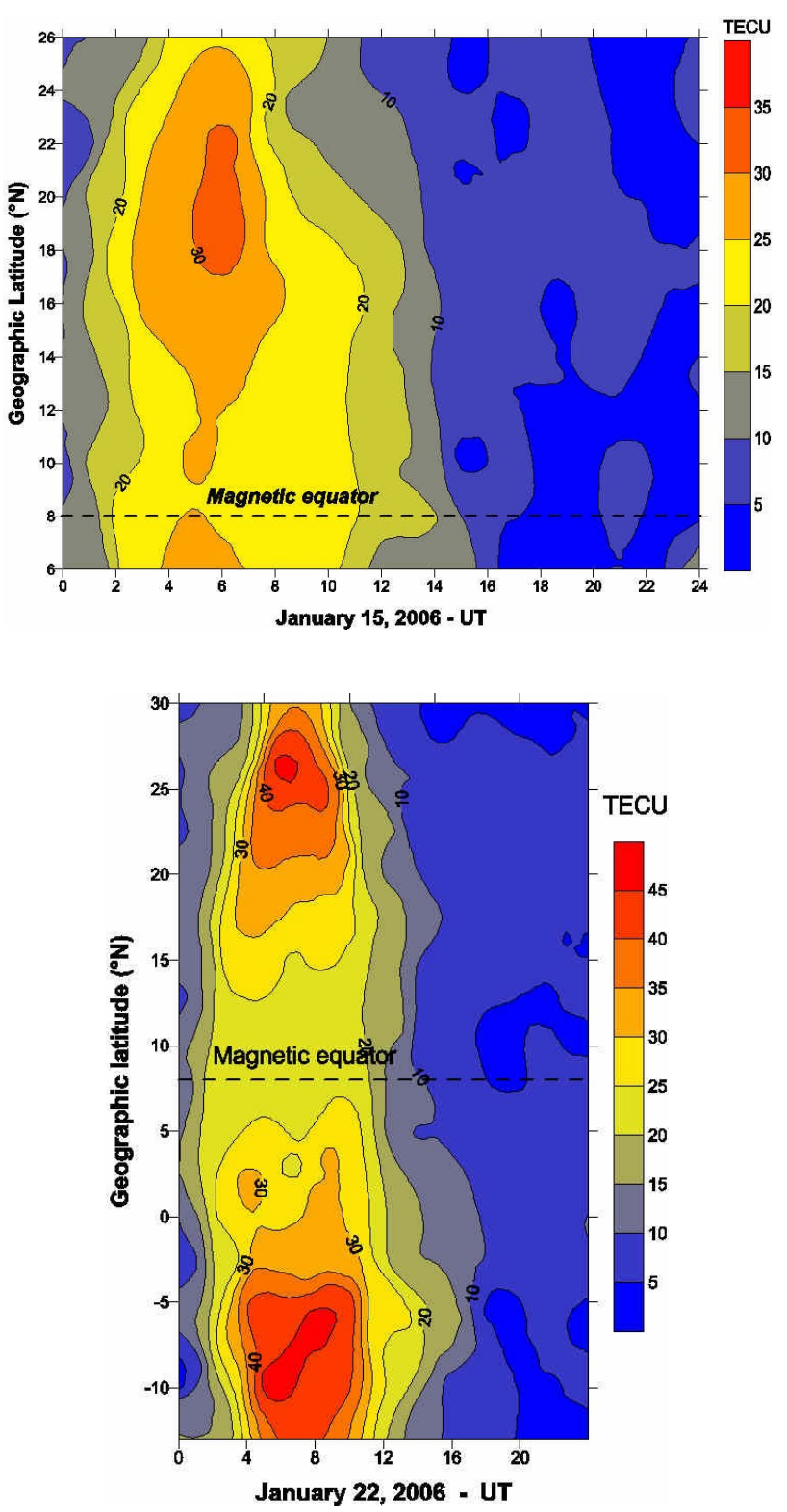

Fig. 6. Total electron content derived from GPS stations. The top panel corresponds to the observations above Vietnam on 15 January 2006 and the bottom panel to the Asian sector on 22 Januray 2006.

Delta, with class 3 being composed of only one station (Bac Quang). These northern regions register higher rainfall amounts than elsewhere in Vietnam: more than 500 and $900 \mathrm{~mm}$ in July, and $2340 \mathrm{~mm}$ and $4850 \mathrm{~mm}$ for the respective annual amounts. Interannual variability does not exhibit any significant signal but just a concentration of energy around 3.1 years.

By contrast the coastal stations between $12^{\circ} \mathrm{N}$ and $19^{\circ} \mathrm{N}$ (classes 4 and 5 in yellow and light blue, respectively) have very similar annual cycles marked by a rainfall peak centred in October (about $600 \mathrm{~mm}$ ). These widespread heavy rains 


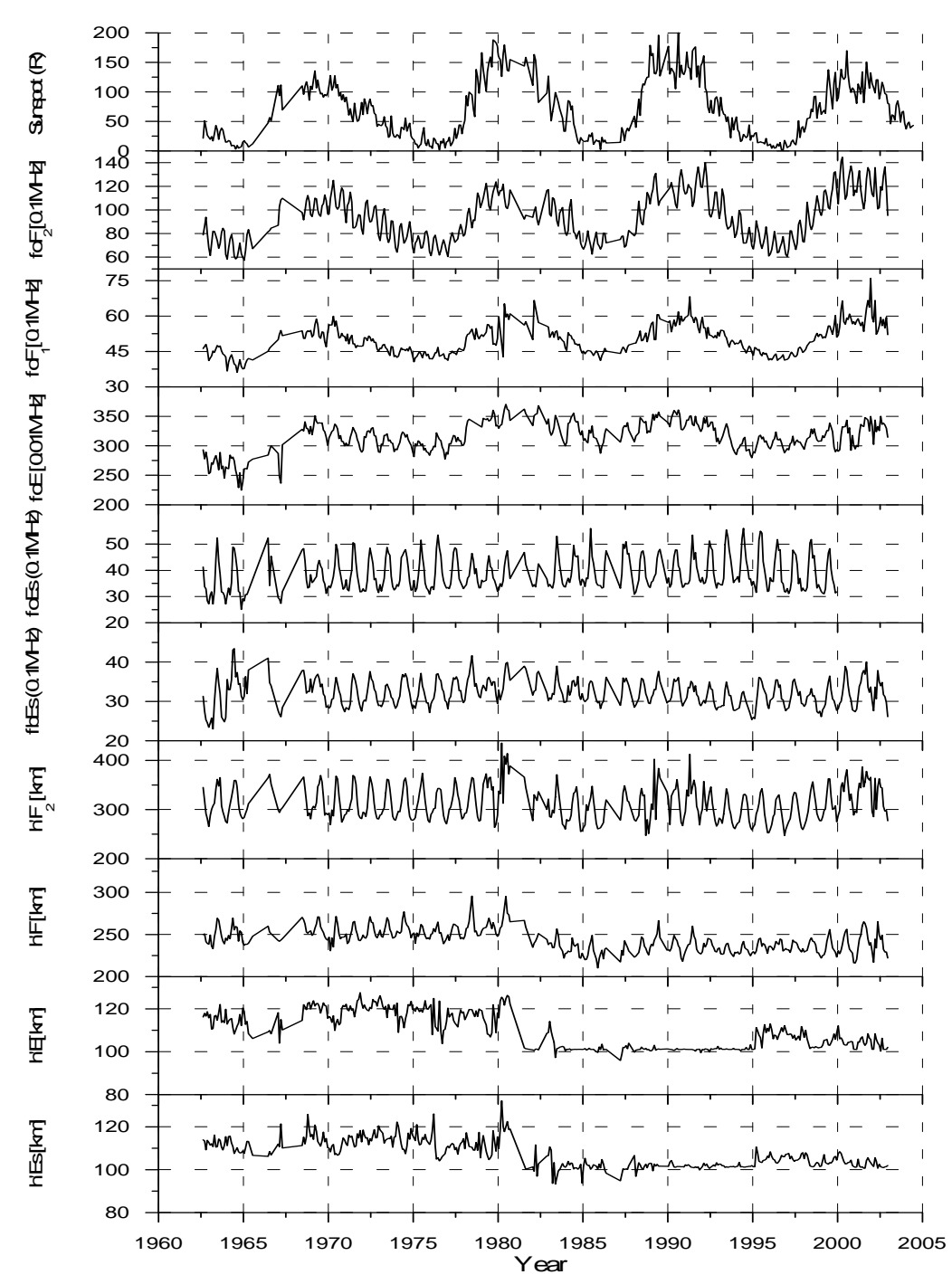

Fig. 7. Ionospheric parameters recorded at Phu Thuy during four solar cycles, from the top to the bottom, the curves are as follows: the sunspot number, the critical frequencies of the F2, F1, E and Es layers and the virtual heights of the F2, F1, E, and Es layers.

are associated with a greater occurrence of synoptic systems, such as thyphoons and tropical depressions, often combining with cold air advections (Dao and Nguyen, 2003), at the beginning of the northeast monsoon season (Fig. 8a). Lower amounts occur during the summer monsoon: this is due to the protection of mountains located south and west of these coastal lowlands: the middle part of Vietnam is on the eastern side of the Truong Son high mountain ridge. Annual amounts are important $(2340 \mathrm{~mm}$ and $2060 \mathrm{~mm}$ for classes 4 and 5, respectively). Notice, however, that these two regions differ regarding the interannual variability with a negative (positive) trend over the most recent period for region 4 (region 5). No significant quasi-biennal cycle is detected by spectral analyses.
Class 6 describes the southernmost region and records a wet season from May to November (more than $400 \mathrm{~mm}$ in August and $2680 \mathrm{~mm} /$ year), with short-lived but heavy rainfall of convective origin. The interannual variability is also marked by a positive trend in recent years with a slight but not significant concentration of variance around 2.4 years.

Figure 11 represents the global distribution of total lightning flash density observed by the LIS, from January 1998 to December 2004, above the Vietnam territory with the grid $0.25^{\circ} \times 0.25^{\circ}$. Data provided by the NASA Lightning Imaging Sensor (LIS) instrument team and the LIS data center via the Global Hydrology Resource Center (GHRC), located at the Global Hydrology and Climate Center (GHCC), Huntsville, Alabama. Vietnam is one of the countries most influenced by lightning. In Fig. 11 we observe some areas of strong lightning in the north and south of the country. In 

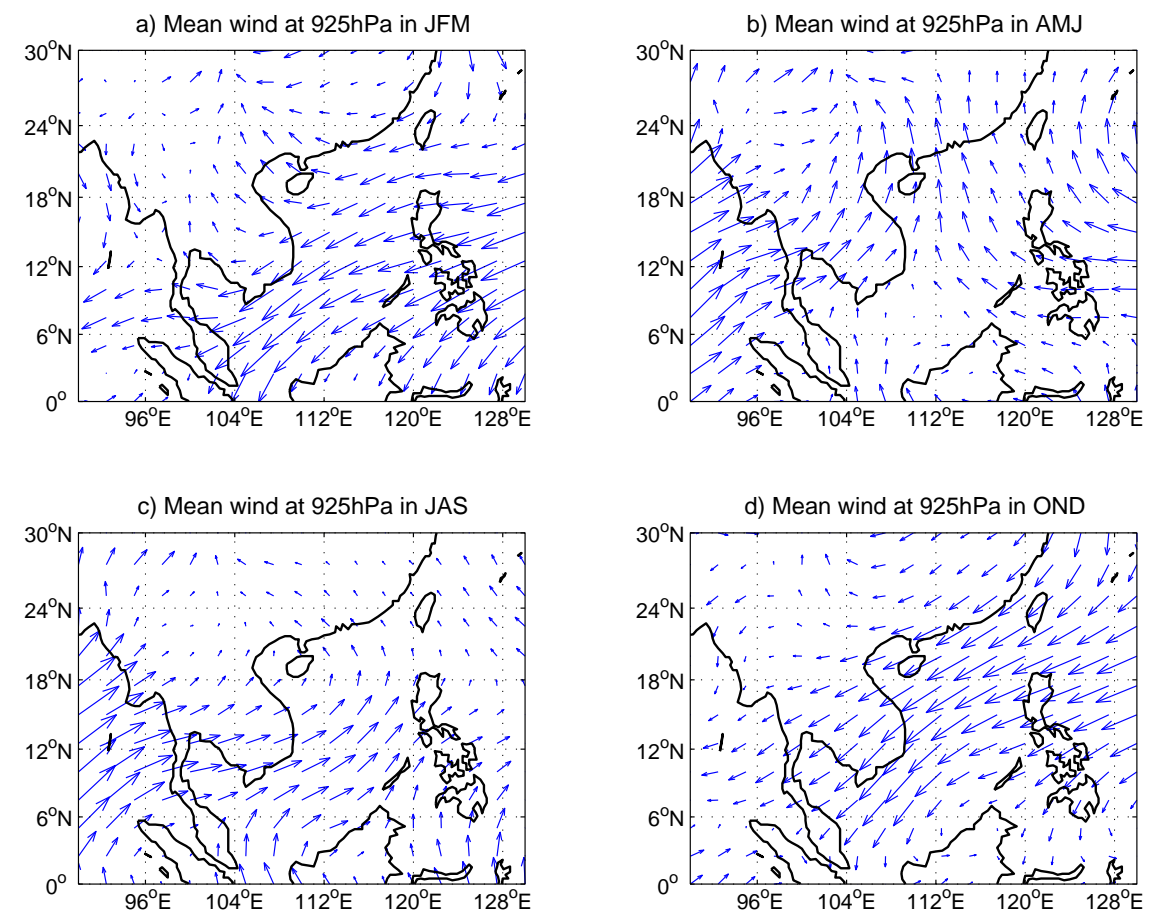

Fig. 8. Mean annual evolution of wind at 925 hPa: JFM: January to March; AMJ: April to June; JAS: July to September; OND: October to December. Period 1979-2004.
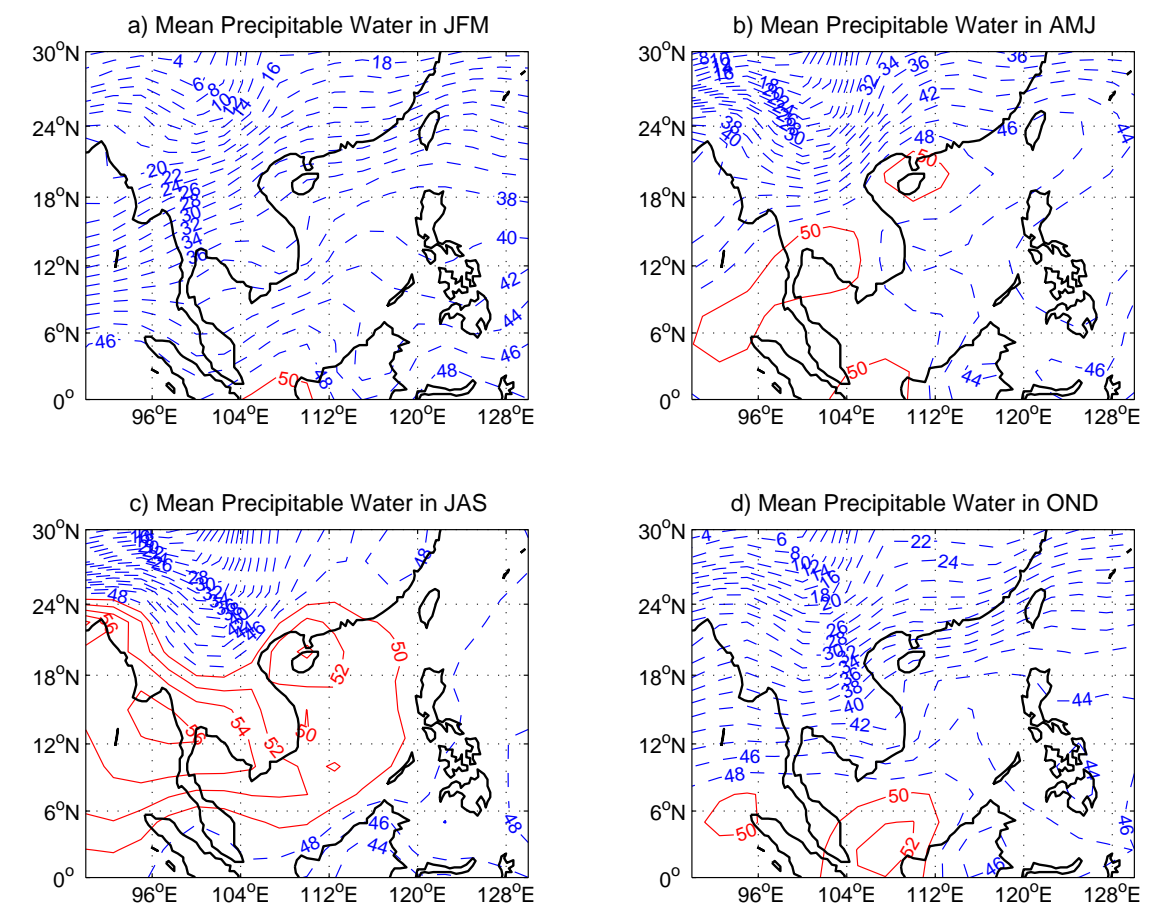

Fig. 9. Mean annual evolution of precipitable water $\left(\mathrm{g} / \mathrm{m}^{2}\right)$ by season. Solid (dashed) lines in red (blue) for values higher (lower) than 50 $\mathrm{g} / \mathrm{m}^{2}$. Period 1979-2004. 


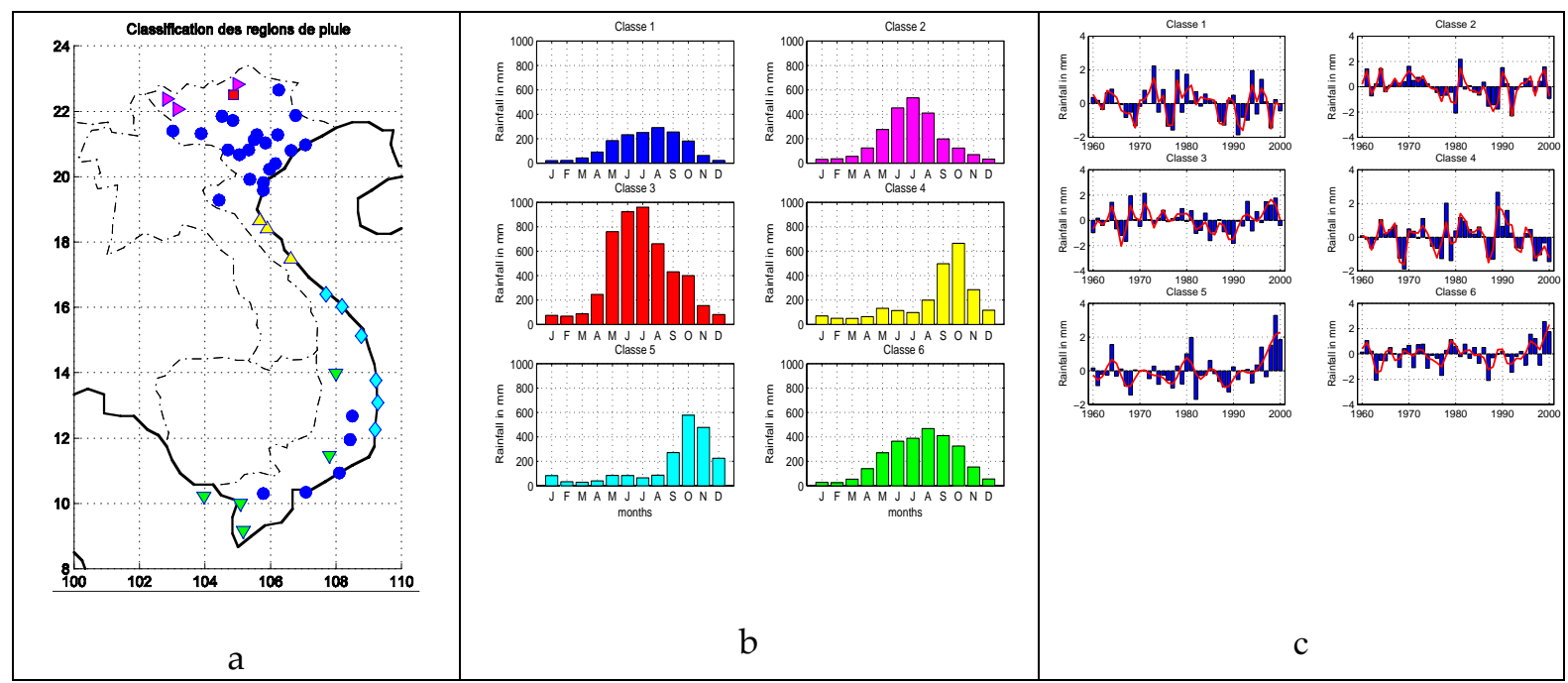

Fig. 10. Rainfall above Vietnam ( 40 rain gauges) over the period 1960-2000: (a) the 6 classes of in-situ stations using K-means clustering; (b) mean annual evolutions (monthly rainfall in $\mathrm{mm}$ ) by class; (c) annual rainfall amounts (bars) and filtered signal (curves) by class. Period 1960-2000.

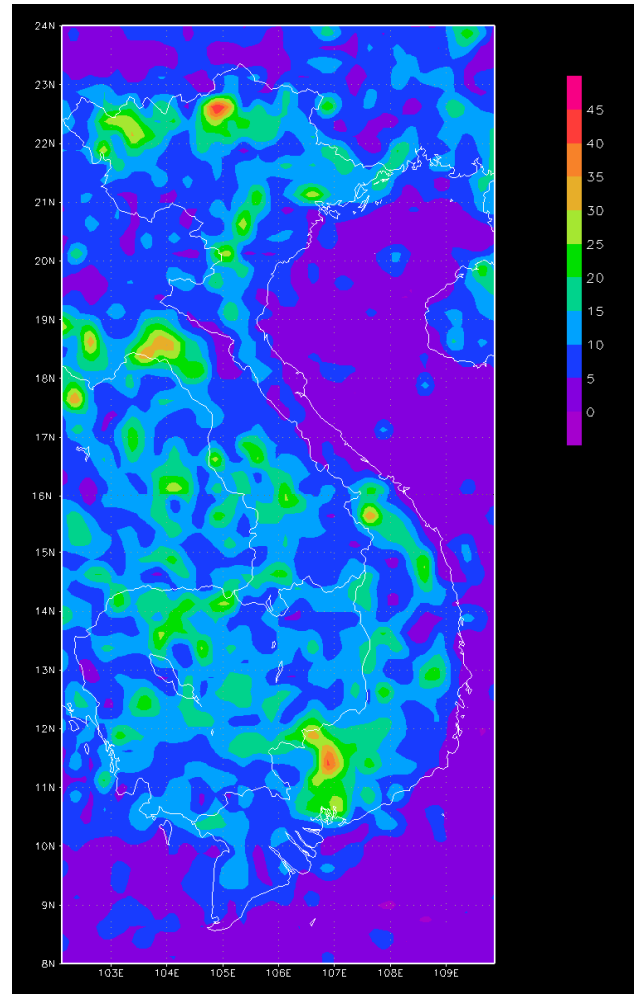

Fig. 11. The global distribution of total lightning flash density observed by the LIS (January 1998-December 2004) above Vietnam territory with the grid $0.25^{\circ} \times 0.25^{\circ}$. The data available from the GHRC are restricted to LIS science team collaborators and to NASA EOS and TRMM investigators. the north Vietnam at the latitude around $22^{\circ} \mathrm{N}$ and longitude $105^{\circ} \mathrm{E}$, the strongest lightning area is also the place with the maximum rainfall (see Fig. 10 red square).

\subsection{Comparison between different longitude sectors}

Figure 12 presents the total electron content maps for the Asian and the American sectors during the magnetic storm of 24 August 2005. At the present time, it is not possible to present a comparison with the African sector, due to a lack of data, but for the future it will be possible, as the international community is planning the installation of GPS stations and magnetometers in Africa in the frame of two international projects, IHY and CAWSES.

Figure 12a presents the total electron content in the Asian sector and Fig. 12b in the American sector. In this figure we point out the magnetic equator the sudden Storm Commencement (SSC) and the storm recovery phase which occurs just after the main phase of the storm. The two dashed lines delimit the main phase of the storm. The main phase of the storm occurs at different local times in each sector and this fact explains a part of the discrepancies in the response to the storm between the Asian and American sectors (Le Huy and Amory-Mazaudier, 2005). We observe a strong difference between the Asian and American sectors. The total electron content amplitude is stronger in the Asian sector, where the two crests exhibit rather the same amplitudes, except on the last day of the period, on 28 August 2005. In Fig. 12a, in the Asian sector the storm starts during the daytime, and we can identify an increase in the TEC at the equator (yellow tongues) just before the beginning of the recovery phase of the storm. On the day after the storm we observe a decrease 

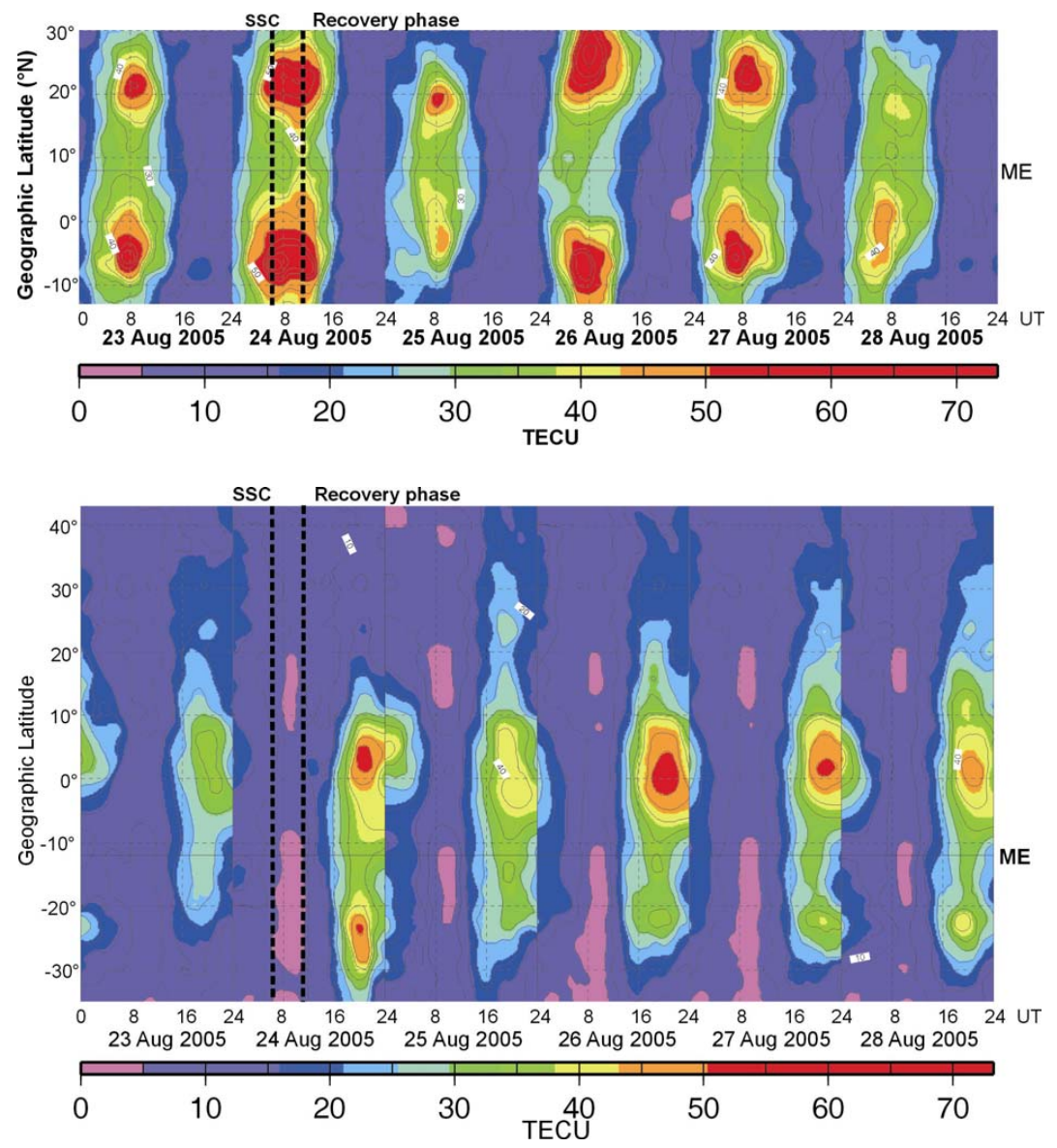

Fig. 12. Maps of total electron content (TEC) in the Asian sector (top panel) and the American sector (bottom panel) during the storm of 24 August 2005. Two vertical dashed lines underline the sudden storm commencement and the beginning of the recovery phase of the storm.

in the amplitude of the total electron density due to the storm dynamo wind effect. In Fig. 12b, in the American sector the asymmetry between the two hemispheres is stronger than in the Asian sector. The southern crest exhibits the strongest amplitude on 24 August 2005, the storm day. On the day after the storm the northern crest amplitude in the American sector decreases, as in the Asian sector one. But one can observe that on 23 August, the day before the storm the northern crest amplitude in the American sector is very small, and on 28 August, four days after the storm the northern crest amplitude in the Asian sector is also very small. It seems necessary to analyse large data sets to understand the day-to-day variability of the total electron content in term of solar radiations and solar wind sources.

\section{Conclusions}

In this paper we present the main morphological features of the Vietname concerning the Earth's magnetic field, the ionosphere, meteorology and lightning. The strong ampli- tude of the Earth's magnetic field at the equator, observed at high altitudes with the CHAMP satellite, is also observed at ground level. The amplitude of the Earth's magnetic field is stronger in the Vietnamese longitude than in the Indian one; this regional observation is not yet explained. The Vietname, which covers tropical and equatorial latitudes, exhibits the ionospheric well-known pattern: the electronic densities have maxima in North Vietnam $\left(+15^{\circ} \mathrm{N}\right.$ magnetic) and minima at the equator, with these features being related to the equatorial fountain process.

In Vietnam the monsoon and lightning are intense. The monsoon has mainly one rainy season, peaking in August and associated with a southwest monsoon flow. But some variabilites of the monsoon are observed in the northern mountainous regions of Vietman and near the coasts. In North Vietnam (latitude $22^{\circ} \mathrm{N}$, longitude $105^{\circ} \mathrm{E}$ ), and South Vietnam (latitude $11^{\circ} \mathrm{N}$, longitude $107^{\circ} \mathrm{E}$ ), there are two regions of very intense lightning, the north one is associated with the strongest precipitation rate observed in Vietnam. 
For the next year, due to the deployment of GPS stations and magnetometers in Africa (in the frame of the CAWSES and IHY programs), the difference between the Vietnamese geophysical environment and the African one must be explained in terms of the global planetary pattern of the Earth's magnetic field, ionosphere, and atmosphere. Such studies were not feasible in the past. They are now becoming possible, and the Vietnamese results become an important contribution to understanding the global environment.

Acknowledgements. The authors acknowledge the following institutions: the French foreign Ministry and the Centre National de la Recherche Scientifique for funding four students scholarships, the Institute of Geophysics and the Vietnamese Academy of Sciences for funding 8 positions for young scientist to work in this project, the French Universities of Brest and Rennes for providing a GPS network, the National Institute of Information and Communication technology (NICT) of Japan for providing an ionosonde at Baclieu, the Indian Institute of Geomagnetism for the Indian geomagnetic data, and R. Gendrin, President of IAGA (International Association for Geomagnetism and Aeronomy) from 1987 to 1991, for his gift of 130 scientific books to the library of the Hanoï Institute of Geophysiscs.

Topical Editor M. Pinnock thanks two referees for their help in evaluating this paper.

\section{References}

Amory-Mazaudier C.: Contribution à l'étude des courants électriques, des champs électriques et des vents neutres ionosphériques de moyennes latitudes, variation régulière et variations perturbées. Etudes de cas à partir des observations du sondeur à diffusion incohérente de Saint-Santin en relation avec les observations du champ géomagnétique terrestre, Volume 1 synthèse / Volume 2 - Articles / Volume 3 - Annexes Techniques, Thèse de Doctorat d'Etat, Paris VI, 1983.

Amory-Mazaudier, C.: Kobea, A., Vila, P., Achy-Séka, A., Blanc, E., Boka, K., Bouvet, J., Cécile, J.-F., Cohen, Y., Curto, J.-J., Dukhan, M., Doumouya, V., Fambitakoye, O., Farges, T., Goutelard, C., Guisso, E., Hanbaba, R., Houngninou, E., Kone, E., Lassudrie-Duchesne, P., Leroux, Y., Menvielle, M., Obrou, O., Petitdidier, M., Ogunade, S.-O., Onwumechili, C.-A., Rees, D., Sambou, E., Sow, M., Vassal, J., and Lathuillere, C.: On Equatorial geophysics studies: The IGRGEA results during the last decade, J. Atmos. S.-P., 67(4), 301-313, 2005.

Axford, W. I. and Hines, C. O.: A unifying theory of high latitudes geophysical phenomena and geomagnetic storms, Can. J. Phys., 39, 1433-1464, 1961.

Blanc, M. and Richmond, A.: The Ionospheric disturbance dynamo, J. Geophys. Res., 85, 1669-1686, 1980.

Chapman, S. and Bartels, J.: Geomagnetism, Oxford University Press New York, 1940.

Chapman, S. and Lindzen, R. S.: Atmospheric tides, D. Reidel publishing company, Dordrecht-Holland, 1970.

Chen, T. C. and Chang, C. P.: Structure and vorticity budget of early summer monsoon trough (Mei-Yu) over southeastern China and Japan, Mon. Wea. Rev., 108, 942-953, 1980.
Dao, T. L. and Nguyen, T. T. T.: Evaluating the role of weather situations, generating heavy and wide spread rainfall in the central and south regions for now casting weather using weather radar information, Journal of Hydrography-Meteorology, Vietnam, 7, 33-41, 2003.

Delouis, H. and Mayaud, P.-N.: Spectral analysis of the geomagnetic activity index aa over a 103-year interval, J. Geophys. Res., 80(34), 4681-4688, 1975.

Doumouya, V. and Cohen, Y.: Improving and testing the empirical equatorial electrojet model with CHAMP satellite data, Ann. Geophys., 22, 3323-3333, 2004,

http://www.ann-geophys.net/22/3323/2004/.

Dungey, T. W.: Interplanetary magnetic field and the auroral zones, Phys. Rev. Lett., 6, 47-48, 1961.

Friedman, H.: Sun and Earth, Scientific American Library, 1986.

Fukao, S., Hashiguchi, H., Yamamoti, M., Tsuda, T., Nakamura, T., and Yamamoto, M. K.: Equarorial Atmosphere radar (EAR): System description and first results, Radio Science, 38(3), 10531066, 2003.

Gurubaran, S., Rajaram, R., Nakamura, T. and Tsuda, T.: Interannual variability of diurnal tide in the tropical region: A signature of El Nino-Southern Ocscillation (ENSO), Geophys. Res. Lett., 32, L13805, doi:10.1029/2005GL022928, 2005.

Hagan, M. E. and Forbes, J. M.: Migrating and nonmigrating diurnal tides in the middle and upper atmopshere excited by tropospheric latent heat release, J. Geophys. Res., 107(D24), 47544764, 2002.

Kanamitsu, M., Ebisuzaki, W., Woolen, J., Yarg, S. K., Hnilo, J.-J., Fiorino, M., and Potter, G. L.: NCEP-DOE AMIP-II reanalysis (R-2), Bulletin of American Meteorological Society, 83, 16311643, 2002.

Kobéa, A. ., Richmond, A. D., Emery, B. A., Peymirat, C., Lühr, H., Moretto, T., Hairston, M., and Amory-Mazaudier, C.: Electrodynamic Coupling of High and Low Latitudes Observations on May 27, 1993, 105(A10), 22 979-22 989, 2000.

Legrand, J. P. and Simon, P. A.: Solar Cycle and geomagnetic activity: A review for geophysicists, Part I, The contributions to geomagnetic activity of shock waves and of the solar wind, Ann. Geophys., 7, 565-578, 1989,

http://www.ann-geophys.net/7/565/1989/.

Le Huy, M.: Diurnal geomagnetic variation in Vietnam and counterelectrojet, J. Sciences of the Earth, NCST of Vietnam, 20(3), 189-199, 1998.

Le Huy, M.: Sudden commencements of magnetic storms observed in Vietnam and in India, J. Sciences of the Earth, NCST of Vietnam, 21(1), 14-25, 1999.

Le Huy, M. and Pham Van, T.: Time variation of the E and F layers at Phu Thuy, Vietnam, J. Sciences of the Earth, NCST of Vietnam, 23(1), 56-59, 2001.

Le Huy, M. and Amory-Mazaudier, C.: Magnetic signature of the Ionospheric disturbance dynamo at equatorial latitudes: "Ddyn", J. Geophys. Res., 10, 10301-10314, 2005.

Maurer, E. P., O’Donnell, G. M., and Lettenmaie, D. P.: Evaluation of the Land Surface Water Budget in NCEP/NCAR and NCEP/DOE Reanalyses using an Off-line Hydrologic Model, J. Geophys. Res., 106(D16), 17 841-17 862, 2002.

Mayaud, P. N.: Analyse morphologique de la variabilité jour-à-jour de la variation journalière régulière $S_{R}$ du champ magnétique terrestre, $\mathrm{I}$ - le système de courants $\mathrm{Cp}$ (régions polaires et sub- 
polaires), Ann. Géophys., 21, 369-401, 1965a.

Mayaud, P. N.:Analyse morphologique de la variabilité jour-à-jour de la variation journalières régulière $S_{R}$ du champ magnétique terrestre, II - le système de courants $\mathrm{C}_{M}$ (régions non-polaires), Ann. Géophys., 514-544, 1965b.

Mayaud, P. N.: The aa indices: a 100-year series characterizing the magnetic activity, J. Geophys. Res., 77, 34, 6870, 6874, 1972.

Mayaud, P. N.: A hundred series of Geomagnetic data 18681967, indices aa, Storm sudden commencements, AIGA Bulletin $\mathrm{n}^{\circ}$ 33, IUGG Publication Office, 252, 1973.

Mayaud, P. N.: Analysis of storm sudden commencements (S.S.C.) for the years 1868-1967, J. Geophys. Res., 80, n 1, 111-122, 1975.

Mazaudier C. and Venkateswaran, S. V.: Delayed ionospheric effects of March 22, 1979 studied by the sixth Coordinated Data Analysis Workshop (CDAW-6), Ann. Geophys., 8, 511-518, 1990, http://www.ann-geophys.net/8/511/1990/.

Mazaudier, C., Achache, J., Achy-Séka, A., Albouy, Y., Blanc, E., Boka, K., Bouvet, J., Cohen, Y., Diatta, C.-S., Doumouya, V., Fambitakoye, O., Gendrin, R., Goutelard, C., Hamoudi, M., Hanbaba, R., Hougninou, E., Huc, E., C., Kakou, K., Kobea Toka, A., Lassudrie-Duchêne, P., Mbipom, E., Menvielle, M., Ogunade, S.-O., Olinloye, J.-O., Rees, D., Richmond, A., Sambou, E., Schmucker, E., Tireford, J.-L., Vassal, J., and Vila, P.: International Equatorial Electrojet Year, Brazilian Journal of Geophysics, 11(3), 303-317 (special issue), 1993.

Nishida, A.: Coherence of geomagnetic DP2 fluctuations with interplanetary magnetic variations, J. Geophys. Res., 73, 5549-5559, 1968.
Nishida, A., Iwasaki, T., and Nagata, T.: The origin of fuctuations in the equatorial electrojet: a new type of geomagnetic variation, Ann. Geophys., 22, 478-484, 1966, http://www.ann-geophys.net/22/478/1966/.

Petitdidier, M. and Laroche, P.: Lightning observations with the Strato-Tropospheric UHF and VHF radars at Arecibo, Puerto Rico, Atmos. Res., 76, 481-492, 2005.

Richard, P., Delannoy, A., Labaune, G., and Laroche, P.: Results of spatial and temporal characterization of the VHF-UHF radiation of lightning, J. Geophys. Res., 91, 1248-1260, 1986.

Simon, P. A. and Legrand, J.-P.: Solar Cycle and geomagnetic activity: A review for geophysicists, Part II, The solar sources of geomagnetic activity and their links with sunspot cycle activity, Ann. Geophys., 7, 579-594, 1989, http://www.ann-geophys.net/7/579/1989/.

Stewart, B.: Terrestrial magnetism, Encyclopedia Britannica, 9th ed., 16, 159-184, 1882.

Truong Quang, H., and Le Huy Minh, M.: Some characteristics of the geomagnetic variations in Vietnam, J. Sciences of the Earth, NCST of Vietnam, 9(1), 7-13, 1987.

Vasyliunas, V. H.: Mathematical Model of magnetospheric processes and its coupling to the ionosphere, in: Particles and Fields in the magnetosphere, edited by: Mc Cormac, B. M., D. Reidel, Dordrecht, Holland, 60-71, 1970.

Zhang, Y., Li, T., Wang, B., and Wu, G.: Onset of the Summer Monsoon over the Indochine Peninsula: climatology and Interannual variations, Journal of Climate, 15,22, 3206-3221, 2002. 